\title{
Opracowanie listy źródeł „Słownika polskiej terminologii prawosławnej"
}

\author{
Jarosław Charkiewicz \\ Warszawska Metropolia Prawosławna \\ Polska \\ wiadomosci@orthodox.bialystok.pl
}

\begin{abstract}
J. Charkiewicz, Development of the list of sources of the “Dictionary of Polish Orthodox Terminology”, Elpis, 20 2018: $181-186$.
\end{abstract}
\begin{abstract}
The Polish Orthodox terminology has not been yet thoroughly elaborated or clearly defined. Wishing to fill this gap, a group of Orthodox theologians and linguists undertook the task of developing "Dictionary of Polish Orthodox Terminology". The first practical stage of this work (apart from the preliminary definition of the scope of the vocabulary) has become the preparation of a possibly full list of basic sources, from which the vocabulary will be excerpted, which will be defined in the dictionary.

In order to prepare a list of words and terms to the dictionary, two areas of sources related to the lexicon concerning Orthodoxy were distinguished: non-specialized sources and specialized sources. The first group includes dictionary and lexicographic sources, including: general dictionaries, bilingual dictionaries and reference books as well as specialist dictionaries and reference books, i.e. specific to Orthodoxy. The second group includes bibliographic items on various aspects of teaching, broadly understood life, organization and activities of the Orthodox Church, which have been grouped into three sections: doctrine, law and practice.

The article discusses the process of distinguishing those sources that have been recognized by the abovementioned a group of researchers for basic. They were briefly discussed and presented in a chronological order as part of the article. In addition, the research team considered it necessary to prepare a "Bibliography" of other sources, which, if possible, will be also used during the development of entry articles.

The list of selected basic non-specialized and specialized sources seems to be so complete that, based on it, it is possible to get rid of the complete list of words and terms that will be presented in the "Dictionary of Polish Orthodox Terminology".

Streszczenie: Polska terminologia prawosławna nie doczekała się dotychczas gruntownego opracowania ani też przejrzystej definicji. Pragnąc wypełnić tę lukę grupa prawosławnych teologów i językoznawców podjęła się trudu opracowania „Słownik polskiej terminologii prawosławnej". Pierwszym praktycznym etapem tej pracy (poza wstępnym określeniem zakresu słownictwa) stało się sporządzenie możliwie pełnej listy podstawowych źródeł, z których ekscerpowane będzie słownictwo, które zostanie zdefiniowane w słowniku. W celu przygotowania siatki haseł do słownika wyodrębniono dwa obszary źródeł związanych z leksyką dotyczącą prawosławia: źródła niewyspecjalizowane i źródła wyspecjalizowane. W pierwszej grupie znalazły się źródła słownikowe i leksykograficzne, a tym: słowniki ogólne, słowniki i leksykony dwujęzyczne oraz słowniki i leksykony specjalistyczne, tj. dotyczące konkretnie prawosławia. W drugiej grupie znalazły się pozycje bibliograficzne dotyczące rozmaitych aspektów z zakresu nauczania, szeroko rozumianego życia, organizacji i działalności Cerkwi prawosławnej, które zostały pogrupowane w trzy działy: doktryna, prawo i praktyka.

Artykuł stanowi omówienie procesu wyodrębniania tych źródeł, które zostały uznane przez ww. grupę badaczy za podstawowe. Zostały on w ramach artykułu pokrótce omówione i przedstawione w układzie chronologicznym. Ponadto zespół badawczy uznał za niezbędne sporządzenie „Bibliografii” innych źródeł, które, w miarę możliwości, zostaną wykorzystane w trakcie opracowania artykułów hasłowych.

Wykaz wybranych podstawowych źródeł niewyspecjalizowanych i wyspecjalizowanych wydaje się być na tyle kompletny, że w oparciu o niego ma szanse zostać wyekscerpowany w miarę kompletny wykaz haseł, które zostaną zaprezentowane w „Słowniku polskiej terminologii prawosławnej".
\end{abstract}

Keywords: Orthodox terminology, Orthodoxy, Orthodox Church, dictionary, lexicon, doctrine, law, practice

Słowa kluczowe: terminologia prawosławna, prawosławie, Cerkiew prawosławna, słownik, leksykon, doktryna, prawo, praktyka

Polska terminologia prawosławna, rozumiana ogólnie jako zbiór terminów dotyczących życia i organizacji Cerkwi prawosławnej, nie doczekała się dotychczas gruntownego opracowania. Co więcej, wydaje się, że nie doczekała się ona również, jak dotychczas, przejrzystej definicji. Pragnąc wypełnić tę lukę, w środowisku prawosławnych teologów i językoznawców z Białegostoku, powstała idea opracowania ,Słownik polskiej terminologii prawosławnej". Realizacja tego projektu możliwa jest w ramach grantu z konkursu Narodowego Programu Rozwoju Humanistyki. Jednostką naukową realizującą projekt jest Wydział Filologiczny Uniwersytetu w Białymstoku.
Głównym celem projektu jest opracowanie słownika zawierającego polskojęzyczną prawosławną terminologię religijną, a zarazem sformalizowanie badań leksykograficznych związanych z terminologią prawosławną. Potrzeba taka, czy wręcz niezbędność powstania przedmiotowego słownika, wynika nie tylko bezpośrednio $\mathrm{z}$ braku kompleksowego normatywnego opracowania tej terminologii w języku polskim, ale również ze wskazań i potrzeb środowisk naukowych oraz wydawnictw, publikujących w języku polskim oryginalne i przekładowe prace dotyczące prawosławnej teologii i kultury. 
Pomimo podejmowanych w różnym czasie i zakresie starań polskich i zagranicznych naukowców i wydawnictw popularnonaukowych mających na celu usystematyzowanie terminologii prawosławnej w języku polskim, problem ten do dzisiaj nie został kompleksowo rozwiązany. Efektem tych prac są jedynie stopniowo pojawiające się jednoi dwujęzyczne słowniki terminologiczne dotyczące leksyki religijnej Cerkwi prawosławnej, które mają jednak charakter rejestracyjny, notujący i objaśniający leksykę danego obszaru tematycznego, ale nie wskazują na aspekt poprawności terminów. Leksykony jednojęzyczne ukazują najczęściej leksykę Prawosławia w sposób wybiórczy, niepełny bądź dotyczący wąskiej gałęzi całej dziedziny. Źródła te są pomocne przede wszystkim w pracy tłumaczy, jednak z powodu braku kompleksowości omawianej przez nie leksyki w szerszym kontekście językowym, często proponują nieadekwatne z punktu widzenia teologii prawosławnej rozwiązania translatorskie, niejednokrotnie stanowiące mniej lub bardziej udane kalki i zapożyczenia z obszaru leksykalnego Kościoła rzymskokatolickiego.

Pierwszymi stricte prawosławnymi próbami przezwyciężenia powyższych braków w dwujęzycznym opisie leksykograficznym leksyki Prawosławia wydają się być w ostatnich latach dwie prace: wydany w 2014 r. „Leksykon terminologii prawosławnej rosyjsko-polski” H. Fediukiny i wydana dwa lata później „Specyfika polskiej terminologii prawosławnej. Koncepcja normatywizacji pisowni”, współautorstwa abp. Jakuba Kostiuczuka, ks. Jerzego Tofiluka, ks. Marka Ławreszuka, ks. Włodzimierza Misijuka i Jarosława Charkiewicza.

Zespół realizujący projekt, efektem którego ma być „Słownik polskiej terminologii prawosławnej”, postawił przed sobą, zatem, bardzo ambitny cel przeprowadzenia kompleksowej analizy wszystkich istniejących w języku polskim terminów związanych z Prawosławiem, aby w efekcie tego powstał kompleksowy i pełny, na ile to możliwe, słownik wypełniający istniejącą w tej dziedzinie lukę. Pierwszym praktycznym etapem tej pracy (poza wstępnym określeniem zakresu słownictwa) stało się sporządzenie możliwie pełnej listy podstawowych źródeł, z których ekscerpowane będzie słownictwo.

Na potrzeby przedmiotowego słownika zespół badawczy mianem polskiej terminologii prawosławnej określił zbiór terminów:

1. związanych z religijnością i duchowością Cerkwi prawosławnej,

2. obejmujących wybraną terminologię chrześcijańską pierwszego tysiąclecia,

3. z zakresu trzech wyodrębnionych aspektów prawosławnego życia religijnego: doktryny (nauczania), prawa i praktyki.

W celu przygotowania siatki haseł do słownika polskiej terminologii prawosławnej, zespół badawczy wyodrębnił dwa obszary źródeł związanych z leksyką dotyczącą prawosławia. Pierwszy z nich stanowią źródła niewyspecjalizowane, a drugi źródła wyspecjalizowane. W pierwszym z tych obszarów znalazły się publikacje w różnym zakresie i stopniu związane $\mathrm{z}$ terminologią prawosławną.
Drugi obszar objął wyłączenie źródła, których głównym polem zainteresowane jest prawosławie.

Pierwszą grupą tekstów, stanowiących materiał do analizy i wyodrębnienia leksyki prawosławnej do planowanego „Słownika polskiej terminologii prawosławnej”, są źródła niewyspecjalizowane, tj. słownikowe i leksykograficzne.

Słowników i leksykonów, będących potencjalnymi źródłami ekscerpcji leksem dotyczących prawosławia jest stosunkowo dużo. Jednocześnie jednak brak jest wśród nich specjalistycznej publikacji leksykograficznej, która w sposób całościowy obejmowałaby terminologię prawosławną w języku polskim. Istniejące słowniki i leksykony niespecjalistyczne, należało poddać gruntownej analizie w celu wyodrębnienia tych, które - $\mathrm{z}$ różnych względów - byłoby najbardziej reprezentatywne, a zarazem zawierały najwięcej terminów mogących, w postaci wyodrębnionych haseł, znaleźć się w „Słowniku polskiej terminologii prawosławnej”. Było to tym bardziej złożone, że pomimo faktu, iż terminologia prawosławia jest obszarem leksykalnym, który coraz bardziej aktywizuje się we współczesnym języku polskim, to na polskim rynku wydawniczym nadal jest niewiele takich pozycji leksykograficznych, które leksykę tę w sposób kompleksowy i klarowny systematyzowały, porządkowały czy normatywizowały.

Analiza doprowadziła do wyodrębnienia ze znacznej liczby słowników i leksykonów sześciu źródeł, które zespół badawczy uznała za bazowe w zakresie leksyki prawosławnej. Nie oznaczało to negacji innych interesujących, często obszernych i wartościowych słowników i leksykonów, a wynikało przede wszystkim z ograniczonych możliwości poddania skrupulatnej analizie większej liczby wydawnictw. Owe sześć źródeł bazowych (w porządku chronologiczny w celu uniknięcia wartościowania), to:

1. „Słownik cerkiewnosłowiańsko-polski” ks. Aleksego Znoski, Prawosławna Diecezja Białostocko-Gdańska (Białystok 1996).

2. „Słownik języka polskiego” pod red. Witolda Doroszewskiego, t. I-XI, Wydawnictwo Naukowe PWN (Warszawa 1996-1997).

3. „Leksykon chrześcijaństwa” Antoniego Markunasa i Tamary Uczytiel, Wydawnictwo Naukowe UAM (Poznań 1999).

4. „Wielki Słownik Wyrazów Obcych PWN” pod. red. Mirosława Bańko, Wydawnictwo Naukowe PWN (Warszawa 2010).

5. „Leksykon terminologii prawosławnej rosyjsko-polski" Heleny Fediukiny, Warszawska Metropolia Prawosławna (Warszawa 2014).

6. „Specyfika polskiej terminologii prawosławnej. Koncepcja normatywizacji pisowni" współautorstwa arcybiskupa Jakuba Kostiuczuka, ks. Jerzego Tofiluka, ks. Marka Ławreszuka, ks. Włodzimierza Misijuka i Jarosława Charkiewicza, Wydawnictwo Uniwersytetu w Białymstoku (Białystok 2016).

Wyodrębnione przez zespół badawczy ww. źródła bazowe można podzielić na trzy grupy: 
1. Słowniki ogólne. Spośród wszystkich słowników ogólnych nie koncentrujących się na tematyce prawosławnej za najbardziej korzystne w celu wyodrębnienie haseł związanych z prawosławiem, uznano „Słownika języka polskiego" pod red. Witolda Doroszewskiego, dzieła klasyczne, a przy tym i popularne wśród czytelników, i dostępne (również on-line w Internecie). Chociaż nie uwzględnia on leksyki najnowszej, to na dzień dzisiejszy słownik ten stanowi najbardziej obszerne normatywne źródło słownictwa polskiego XX w., a co więcej, jest bazę materiałową wielu późniejszych źródeł leksykograficznych. Jego dobrym uzupełnieniem jest z kolei „Wielki Słownik Wyrazów Obcych PWN" pod. red. Mirosława Bańko.

2. Słowniki i leksykony dwujęzyczne. Niezbędność wykorzystania publikacji dwujęzycznych do ekscerpcji haseł wynika z faktu, że poza językiem polskim również inne języki wschodniosłowiańskie do dziś są w częściowym użyciu w życiu religijnym wiernych Cerkwi prawosławnej w Polsce. Część terminologii dotyczącej prawosławia jest zapożyczona z języka staro-cerkiewno-słowiańskiego właśnie poprzez języki wschodniosłowiańskie. Spośród tego rodzaju publikacji zdecydowano się na wspomniane wyżej słowniki i leksykony autorstwa ks. A. Znoski, A. Markunasa i T. Uczitiel oraz H. Fediukinej. Praca ostatniej z wymienionych autorek, pt. „Leksykon terminologii prawosławnej rosyjsko-polski” jest na dzień dzisiejszy zapewne jedyną pracą leksykograficzną traktująca $\mathrm{w}$ miarę całościowo o leksyce duchowości prawosławia.

3. Słowniki i leksykony specjalistyczne. Spośród tego typy prac leksykograficznych zdecydowano się na wykorzystanie w celu wyodrębnienia haseł na opracowanie pt. „Specyfika polskiej terminologii prawosławnej. Koncepcja normatywizacji pisowni". Jest to praca pionierska, a przy tym powstała bardzo niedawno (2016), będąca próbą systematyzacji i pewnego ujednolicenia religijnej terminologii polskiej, która jest współcześnie używana w Cerkwi prawosławnej w Polsce.

Jakie powody, poza wspomnianymi wcześniej ograniczonymi możliwościami poddania skrupulatnej analizie, zdecydowały, że zespół badawczy wyodrębnił właśnie powyższe prace, jednoczesnej eliminując inne? Przyczyny te wymieńmy w porządku całkowicie przypadkowym, aby i tym razem oprzeć się pokusie ich wartościowania i oceniania które z nich są bardziej istotne i ważne, a które mniej:

1. Czas wydania. Już na wstępnym etapie selekcji źródeł, wyłączono słowniki i leksykony wydane przed 1945 rokiem, jako zawierające leksykę częściowo przestarzałą, a częściowo już nie używaną.

2. Dostępność/popularność słowników i leksykonów. Ze źródeł bazowych wyłączono te, które są w małym stopniu dostępne, jak też mało znane współczesnemu czytelnikowi, np. „Praktyczny słownik współczesnej polszczyzny” pod red. H. Zgółkowej, t. 1-50, Poznań 1994-2005.

3. Objętość hasłowa słowników. Bardzo duża liczba jednostek hasłowych słowników w znacznym stopniu utrudnia analizę zaprezentowanej w nich leksyki w stosunkowo krótkim czasie, którym ograniczona jest realizacja omawianego projektu. Dotyczy to np. ww. „Praktycznego słownika współczesnej polszczyzny" pod red. H. Zgółkowej, t. 1-50, Poznań 1994-2005.

4. Ograniczoność tematyczna. Część spośród słowników i leksykonów terminologię prawosławną prezentuje w stopniu marginalnym, a zatem ich uwzględnienie wśród źródeł bazowych nie wnosiłoby istotnego (o ile w ogóle) wzbogacenia leksyki planowanego słownika. Mowa np. o „Słowniku współczesnego języka polskiego” pod red. B. Dunaja, Warszawa 1996.

5. Fragmentaryczność. Zrezygnowano z pozycji poświęconych jedynie niektórym obszarom tematycznym dotyczących prawosławia, a przy tym niewyczerpującym danego tematu, np. „Słownik terminologiczny. Wyposażenia świątyń obrządku Wschodniego z przydatkiem ikon maryjnych” E. Pokorzyny, Warszawa 2001 czy „Zwyczaje i obrzędy prawosławne. Mały słownik" E. Smykowskiej, Warszawa 2015.

6. Selekcja wybiórcza. Niektóre słowniki zostały wyłączone z grupy źródeł bazowych po wybiórczym ich przeanalizowaniu i stwierdzeniu braku obecności podstawowej leksyki związanej z prawosławiem, np. „Wielki słownik języka polskiego PAN" red. P. Żmigrodzki, Instytut Języka Polskiego PAN, Kraków 2007-.

Słowników i leksykonów nie włączone przez zespół badawczy do grupy źródeł bazowych nie należy traktować jako wydawnictw pozbawionych wartości na płaszczyźnie wyodrębnienia haseł do planowanego słownika. One również mogą być w tym względzie pomocne, chociaż nie jako pierwszoplanowe, lecz uzupełniające. $Z$ tego też powodu zespół badawczy część z nich, tych stosunkowo najbardziej przydatnych, umieścił w bibliografii źródeł prac, które są istotne z punktu widzenia leksyki polskojęzycznej związanej z prawosławiem.

Drugim obszarem wyodrębniania haseł polskiej terminologii prawosławnej są źródla wyspecjalizowane. $\mathrm{W}$ ich skład wchodzi wiele pozycji bibliograficznych dotyczących rozmaitych aspektów z zakresu nauczania, szeroko rozumianego życia, organizacji i działalności Cerkwi prawosławnej. W trosce o większą klarowność umownie, chociaż, jak się wydaje, niedoskonale, źródła wyspecjalizowane zostały pogrupowane $\mathrm{w}$ trzy działy: doktryna, prawo i praktyka. Niedoskonale przede wszystkim $\mathrm{z}$ tego powodu, że $\mathrm{w}$ niektórych przypadkach zakwalifikowanie danego źródła do tylko jednego działu nie było oczywiste. Pomimo tego, chociaż niedoskonale, lecz jednak systematyzujący źródła, został zastosowany powyższy trójpodział.

Dział „,doktryna” obejmuje doktrynalną sferę działalności Cerkwi. Zawiera on przede wszystkim teologię dogmatyczną, zasadniczą, moralną i porównawczą. Drugi z działów, „prawo” dotyczy szeroko rozumianej sfery prawnej działalności Cerkwi. Znajdują się w niej: prawo kanoniczne, struktura administracyjna i eklezjalna oraz organizację życia Cerkwi. Trzeci z działów obejmuje praktyczną stronę działalności Cerkwi. Znajdujące się w nim źródła dotyczą przede wszystkim duchowości prawosławnej, elementów życia liturgicznego, modlitewnego, ascetycznego, cerkiewnej architektury, ikonografii i hymnografii. 
Dokonując wyboru podstawowych źródeł wyspecjalizowanych, będących swojego „korpusem” prac, mającym służyć bazą dla wyodrębnienia z nich haseł dla „Słownika terminologii prawosławnej", zespół badawczy kierował się szeregiem zasad. Nie szeregując ich pod względem stopnia ważności, za najważniejsze zasady uznano następujące:

1. Źródłami są wyłącznie wydawnictwa drukowane. Tym samym zrezygnowano z zaliczenia do podstawowych źródeł wyspecjalizowanych niejednorodnej pod względem poziomu i jakości zawartości witryn internetowych zawierających w większym lub mniejszym stopniu terminologię prawosławną $\mathrm{w}$ języku polskim.

2. Wyodrębnione hasła powinny pochodzić z języka pisanego. Podstawowe źródła powinny spełniać wymóg języka pisanego, a nie mówionego czy leksyki regionalnej.

3. Priorytet mają autorzy prawosławni. Pierwszeństwo wśród źródeł mają te, których autorami bądź tłumaczami (przeważnie i jednymi, i drugimi) są osoby wyznania prawosławnego. Wynika to z większej pewności co do odpowiedniego poziomu merytorycznego ich prac na temat prawosławia.

4. Leksyka powinna być możliwie szeroko urozmaicona. Aby jak najszerzej objąć pole badawcze, niezbędne jest sięgnięcie do słownictwa prawosławnego zawartego w pracach na tyle dużej grupy autorów, na ile jest to możliwe, oczywiście biorąc pod uwagę ograniczone możliwości czasowe i osobowe związane z realizacją grantu. Założono zatem, że

5. Wachlarz autorów źródeł powinien być możliwie szeroki. Pomimo tego, że polskie słownictwo prawosławne zostało w niemałym stopniu wypracowane przez kilku autorów, w celu zachowania bogactwa tej leksyki, przy doborze źródeł wyspecjalizowanych starano się zachować takie proporcje, które umożliwiłyby analizę terminologii używanej przez możliwie wielu autorów.

6. Wyodrębniona leksyka powinna być rozpowszechniona i stosowana. Podstawowe źródła powinny zawierać leksykę, która jest już w możliwie dużym stopniu rozpowszechniona i stosowana nie tylko przez wielu autorów prac i thumaczy, ale również osoby piszące na temat prawosławia.

7. Leksyka powinna być współcześnie stosowana. Chociaż pierwsze szersze prace nad polską terminologią prawosławną datowane są na lata międzywojenne, to stosowana wówczas leksyka często stanowiła kalkę z używanego w owym czasie języka polskiego i jest ona już w dużym stopniu przestarzała. Leksyka prawosławna w języku polskim zaczęła się intensywnie rozwijać w latach 90 . XX w., wcześniej czyniąc to jedynie incydentalnie. Zespół badawczy zdecydował, aby właśnie współczesna leksyka powinna być wykorzystywana do przygotowania siatki haseł.

8. Priorytet przynależy źródłom poświęconym terminologii specjalistycznej. Wszędzie gdzie to jest możliwe i uzasadnione, pierwszeństwo nad źródłami zawierającymi głównie ogólną terminologię prawosławna, powinny posiadać źródła poświęcone wąskiej dziedzinie specjalistycznej.
9. Priorytet wykorzystywania wydawnictw oficjalnych. W przypadku kolizji używania różnych terminów, pierwszeństwo należy oddać tym używanym w oficjalnych wydaniach Cerkwi prawosławnej w Polsce, a w szczególności publikacjach zatwierdzonych przez Święty Sobór Biskupów PAKP.

10. Nie jest możliwe opracowanie kompletnej listy źródeł. Zespół badawczy jest świadomy faktu, że swoją pracą w zakresie wyodrębnienia haseł do słownika nie jest w stanie objąć $100 \%$ prawosławnej leksyki w języku polskim, chociaż ma nadzieję, że luki, które pozostaną po powstaniu słownika będą nieznaczne i nieistotne w kontekście całości.

W trosce o jak najszerszy dobór autorów i tłumaczy źródeł, które zespół badawczy uznał za kluczowe w celu wyekscerpowania haseł z zakresu doktrynalnej sfery działalności Cerkwi, zdecydowano się na dziewięć bazowych prac z tej sfery, kilka innych przesuwając do bibliografii. Autorami większości z nich są wybitni teologowie prawosławni: metropolici Hilarion Ałfiejew i Kallistos Ware, o. Aleksander Schmemann, Paul Evdokimov i Włodzimierz Łosski. Ich prace dotyczą różnych dziedzin teologii z obszaru „doktryny”, tj. teologii dogmatycznej, zasadniczej, moralnej i porównawczej. Uzupełnieniem dla ich dzieł są prace innych współczesnych teologów i badaczy: prof. Krzysztofa Leśniewskiego, dr Elżbiety Przybył i dr. Jarosława Charkiewicza. Całość uzupełnia katechizm prawosławny pt. „Bóg żywy. Katechizm Kościoła Prawosławnego" w przekładzie Agnieszki Kuryś.

Najstarszą z powyższych dziewięciu prac, będącą pierwszym szerokim przestawieniem doktryny prawosławnej w języku polskim, jest wydane przez ponad pięćdziesięciu laty „Prawosławie” Paula Evdokimova w thumaczeniu ks. Jerzego Klingera. Kolejną, również wydaną stosunkowo dawno, jest inne klasyczne dzieło z tej dziedziny: „Teologia mistyczna Kościoła Wschodniego” Włodzimierza Łosskiego w przekładzie Marii Sczanieckiej. Do klasycznych pozycji z tej dziedziny bezspornie należy również zaliczyć prace: „Eucharystia. Misterium Królestwa" o. Aleksandra Schmemanna, którą przełożył Andrzej Turczyński, „Misterium wiary. Wprowadzenie do prawosławnej teologii dogmatycznej" metropolity Hilariona Ałfiejewa, w przekładzie Jarosława Charkiewicza i przełożone przez ks. Włodzimierza Misijuka dzieło metropolity Kallistosa Ware „Kościół prawosławny”. Dobrym uzupełnieniem ogólnej terminologii z działu "doktryna” wydaja się być dwie wybrane przez zespół badawczy prace: Elżbiety Przybył „Prawosławie” oraz „Bóg żywy. Katechizm Kościoła Prawosławnego". Ponadto, ze względu na znaczy zasób słownictwa $\mathrm{z}$ dwóch wąskich dziedzin, zdecydowano również o potraktowaniu jako prace bazowe, z których będą ekscerpowane hasła dwie obszerne prace: „Nie potrzebują lekarza zdrowi... Hezychastyczna metoda uzdrawiania człowieka” Krzysztofa Leśniewskiego i „Kult świętych w Kościele prawosławnym” Jarosława Charkiewicza. Pierwsza z nich zawiera wiele, często nie występujących w innych pracach źródłowych, terminów z zakresu duchowości, a druga hagiologii i hagiografii. 
Z związku z dużą liczbą wartościowych źródeł z działu „,doktryna” zespół badawczy zdecydował o przeniesieniu części z nich do bibliografii i wykorzystywaniu ich jedynie uzupełniająco. Podobny problem obfitości w zasadzie nie wystąpił w drugim z działów, na które zostały podzielone źródła specjalistyczne, a mianowicie „prawo”. Stosunkowo ograniczona, w porównaniu z działami ,doktryna” i „praktyka”, polskojęzyczna literatura w tym zakresie, sprawiła, że niemal w całości została ona zaliczona do prac bazowych do wyekscerpowania haseł do słownika. Na literaturę tę złożyły się dwojakiego rodzaju źródła.

1. Prace ks. Aleksego Znosko związane prawem kościelnym:

- „Prawosławne prawo kościelne”, cz. 1 (Warszawa 1973).

- „Prawosławne prawo kościelne. Zagadnienia wybrane”, cz. 2 (Warszawa 1975).

- „Kanony Kościoła Prawosławnego”, t. I i II, przekł. ks. dr Aleksy Znosko (Warszawa 1978, Hajnówka 2000).

2. Zewnętrzne i wewnętrzne dokumenty prawne regulujące działalność Kościoła prawosławnego w Polsce:

- „Ustawa z dnia 4 lipca 1991 r. o stosunku Państwa do Polskiego Autokefalicznego Kościoła Prawosławnego" (Dz. U. z 2014 r., poz. 1726).

- „Statut Wewnętrzny Polskiego Autokefalicznego Kościoła Prawosławnego” („Wiadomości PAKP” 1999, nr 1, s. 4-7).

- „Statut Parafialny Polskiego Autokefalicznego Kościoła Prawosławnego” („Wiadomości PAKP” 1999, nr 2, s. 4-7).

- „Statut Monasterów Męskich i Żeńskich Świętego Polskiego Autokefalicznego Kościoła Prawosławnego” („Wiadomości PAKP” 1999, nr 10, s. 4-7).

Nieżyjący już ks. dr Aleksy Znosko należał do wybitnych znawców kanonów kościelnych. Przez wiele lat był wykładowcą Prawosławnego Seminarium Duchowego w Warszawie i Chrześcijańskiej Akademii Teologicznej w Warszawie. Jego prace do dzisiaj są wykorzystywane przez pracowników naukowych i studentów tych uczelni. Ubolewać można jedynie, że teologowi temu nie udało się zakończyć thumaczenia pełnego tekstu kanonów obowiązujących w Kościele prawosławnym z języka cerkiewnosłowiańskiego na polski (ukazała się tylko pierwsza część, obejmująca Kanony Apostolskie oraz kanony 6 Soborów Powszechnych i 6 kolejnych Soborów Lokalnych).

Podstawowym obowiązującym aktem prawnym regulującym stosunki państwa polskiego i Kościoła prawosławnego w naszym kraju jest wspomniana ustawa z 4 lipca 1991 roku, która była kilkukrotnie nowelizowana, po raz ostatni w 2014 roku. Z kolei głównym wewnątrzkościelnym aktem o charakterze administracyjno-prawnym jest przyjęty w 1995 r. przez Święty Sobór Biskupów PAKP „Statut Wewnętrzny Polskiego Autokefalicznego Kościoła Prawosławnego". Taki sam charakter posiada kilka innych dokumentów, które w kolejnych latach zostały przyjęte przez ten organ. Najważniejsze z nich to Statut Parafialny Polskiego Autokefalicznego Kościoła Prawosławnego" (przyjęty w 1998 r.) i „Statut Monasterów Męskich i Żeń- skich Świętego Polskiego Autokefalicznego Kościoła Prawosławnego" (przyjęty w 1999 r.). Wszystkie te dokumenty zostały opublikowane $\mathrm{w}$ głównym organie prasowym Kościoła prawosławnego w Polsce w 1999 roku.

Pozostałe akty prawne regulujące działalność innych sfer działalności PAKP, mniej istotne z punktu widzenia wyodrębniania leksyki do słownika, zostały umieszczone w dziale „Bibliografia”.

Trzeci zasadniczy aspekt życia religijnego stanowi praktyczna stronę działalności Cerkwi. Zespół badawczy przyjął, że w słowniku polskiej terminologii prawosławnej powinny znaleźć się dwa zasadnicze elementy „praktyki” - liturgika i sztuka sakralna.

Liturgika obejmuje życie modlitewne, nabożeństwa, sakramenty, kalendarz liturgiczny, praktykę liturgiczną, obrzędy i tradycje religijne, a w ramach tej dyscypliny możemy wyróżnić elementy teoretyczne i praktyczne. Sztukę sakralną, będącą praktyczną emanacją wiary, obejmuje architekturę sakralną, ikonografię i śpiew liturgiczny. Każda $\mathrm{z}$ tych grup zawiera elementy charakterystyczne dla duchowości prawosławnej, stanowiące artystyczne, symboliczne lub alegoryczne wyrażenie prawd wiary.

Dla wyekscerpowania haseł do przedmiotowego słownika za bazowe należy uznać oficjalne wydania ksiąg liturgicznych, opublikowanych przez Polski Autokefaliczny Kościół Prawosławny. Za najważniejsze spośród nich zespół badawczy uznał dwa: „Archijeratikon” i „Euchologion”. „Archijeratikon” to księga używana przez biskupa, zawierająca teksty nabożeństw cyklu dobowego, uzupełnione o elementy zmienne cyklu tygodniowego i rocznego, a także teksty sakramentów sprawowanych przez biskupa. Czterotomowy „Euchologion”, w nieznacznym zakresie treściowo pokrywający się z „Archijeratikonem”, zawiera zaś teksty sakramentów, nabożeństw intencyjnych związanych z najróżniejszymi wydarzeniami z życia wspólnotowego $\mathrm{i}$ indywidualnego wiernych Cerkwi prawosławnej, jak też teksty nabożeństw związanych z praktyką życia monastycznego. Terminologię znajdującą się w tych dwóch bazowych księgach liturgicznych uzupełnia oficjalny kalendarz PAKP, będący źródłem leksyki dotyczącej nazewnictwa świąt, świątyń, wydarzeń religijnych, okresów świątecznych i postnych.

Poza wskazanymi głównymi, oficjalnymi źródłami terminologii dotyczącej praktycznej strony działalności Cerkwi, zespół badawczy zdecydował o wyekscerpowaniu leksyki z tym związanej z kilku monografii, poświęconych prawosławnej praktyce liturgicznej i innym kwestiom szeroko pojmowanej „praktyki”. To prace kilku współczesnych teologów i badaczy: ks. ks. Henryka Paprockiego, Marka Ławreszuka, Konstantego Bondaruka i prof. Ivana Petrova, wydane $\mathrm{w}$ różnych ośrodkach naukowych, co pozwala odzwierciedlić zróżnicowanie terminologiczne. Ze względu na wyjątkową rolę ikonografii w Cerkwi prawosławnej, w celu wyodrębnienia związanej z nią terminologii uwzględniono trzy współczesne monografie poświęcone ikonie w prawosławiu, przy czym każda innego autorstwa (Leonid Uspienski, o. Grigorij Krug i Iriny Jazykow) i w przekładach różnych tłumaczy (Maria Żurawska, 
ks. Henryk Paprocki, Roman Mazurkiewicz), co również pozwala uwidocznić pewne rozbieżności dotyczące stosowanej terminologii.

Omówione powyżej bazowe źródła specjalistyczne, w porządku chronologii wydania i w podziale na trzy działy przedstawiają się następująco:

\section{Doktryna}

P. Evdokimov, Prawostawie, przekł. J. Klinger, Warszawa 1964.

W. Łosski, Teologia mistyczna Kościoła Wschodniego, przekł. M. Szczaniecka, Warszawa 1989.

A. Schmemann, Eucharystia. Misterium Królestwa, przekł. A. Turczyński, Białystok 1997.

E. Przybył, Prawosławie, Wydawnictwo „Znak”, Kraków 2000

Bóg żywy. Katechizm Kościoła Prawosławnego, przekł. A. Kuryś, Wydawnictwo WAM, Kraków 2001.

K. Leśniewski, Nie potrzebuja lekarza zdrowi... Hezychastyczna metoda uzdrawiania człowieka, Katolicki Uniwersytet Lubelski, Lublin 2006.

Hilarion (Atfiejew), Misterium wiary. Wprowadzenie do prawosławnej teologii dogmatycznej, przekł. J. Charkiewicz, Warszawska Metropolia Prawosławna, Warszawa 2009.

K. Ware, Kościót prawosławny, przekł. ks. W. Misijuk, Bractwo Młodzieży Prawosławnej w Polsce, Białystok 2011.

J. Charkiewicz, Kult świętych w Kościele prawosławnym, Warszawska Metropolia Prawosławna, Warszawa 2015.

\section{Prawo}

A. Znosko, Prawostawne prawo kościelne, cz. 1, Chrześcijańska Akademia Teologiczna w Warszawie, Warszawa 1973.

A. Znosko, Prawostawne prawo kościelne. Zagadnienia wybrane, cz. 2, Chrześcijańska Akademia Teologiczna w Warszawie, Warszawa 1975.

Kanony Kościoła Prawostawnego, przekł. ks. dr A. Znosko, I i II, Wydawnictwo „Bratczyk”, Hajnówka 2000 .

Ustawy z dnia 4 lipca 1991 r. o stosunku Państwa do Polskiego Autokefalicznego Kościota Prawosławnego (Dz. U. z 2014 r. poz. 1726).

Statut Wewnętrzny Polskiego Autokefalicznego Kościoła Prawostawnego, [w:] „Wiadomości PAKP” 1999, nr 1, s. 4-7.

Statut Parafialny Polskiego Autokefalicznego Kościota Prawosławnego, [w:] „Wiadomości PAKP” 1999, nr 2, s. 4-7.
Statut Monasterów Męskich i Żeńskich Świętego Polskiego Autokefalicznego Kościoła Prawosławnego, [w:] „Wiadomości PAKP” 1999, nr 10, s. 4-7.

\section{Praktyka}

Nauka o nabożeństwach prawostawnych, oprac. ks. K. Bondaruk, Prawosławna Diecezja Białostocko-Gdańska, Białystok 1987.

I. Jazykowa, Świat ikony, przekł. ks. H. Paprocki, Warszawa 1998.

G. Krug, o., Myśli o ikonie, przekł. R. Mazurkiewicz, Białystok 1991.

Nowe tablice, czyli o cerkwi, liturgii, nabożeństwach $i$ utensyliach cerkiewnych, wybór, przekł. Ivan Petrov, Kraków 2007.

L. Uspienski, Teologia ikony, przekł. M. Żurowska, Warszawa 2009

H. Paprocki, Misterium Eucharystii, Wydawnictwo WAM, Kraków 2010.

Archijeratikon, Warszawska Metropolia Prawosławna, Warszawa 2011.

M. Ławreszuk, Modlitwa wspólnoty, Uniwersytet w Białymstoku, Białystok 2014.

Euchologion, t. 1-3, Warszawska Metropolia Prawosławna, Warszawa 2016.

Euchologion monastyczny, Warszawska Metropolia Prawosławna, Warszawa 2016.

Kalendarz prawostawny 2018, Warszawska Metropolia Prawosławna, Warszawa 2017.

Mając na uwadze ograniczone czasowo-osobowe możliwości wyekscerpowania leksyki prawosławnej z dużej liczby źródeł, co przekraczało fizyczne możliwości zespołu badawczego i jego współpracowników, zespół ów kilkukrotnie przeprowadzał konsultacje, w wyniku których zdecydowano o przesunięciu niektórych spośród źródeł, pierwotnie proponowanych jako bazowe, do działu „Bibliografia”. Dokonano tego w oparciu o dziesięć zasad przedstawionych powyżej. Pozycje źródłowe przesunięte do „Bibliografii” zostana również, w miare możliwości, wykorzystane przez zespół badawczy w trakcie opracowania artykułów hasłowych.

Przedstawiony powyżej wykaz wybranych przez grupę badawczą podstawowych źródeł niewyspecjalizowanych i wyspecjalizowanych wydaje się być na tyle kompletny, że w oparciu o niego ma szanse zostać wyekscerpowany w miarę kompletny wykaz haseł, które zostaną zaprezentowane $\mathrm{w}$ „Słowniku polskiej terminologii prawosławnej". 


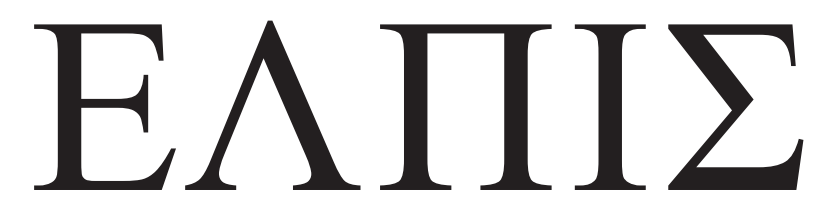

CZASOPISMO TEOLOGICZNE KATEDRY TEOLOGII PRAWOSŁAWNEJ UNIWERSYTETU W BIAŁYMSTOKU

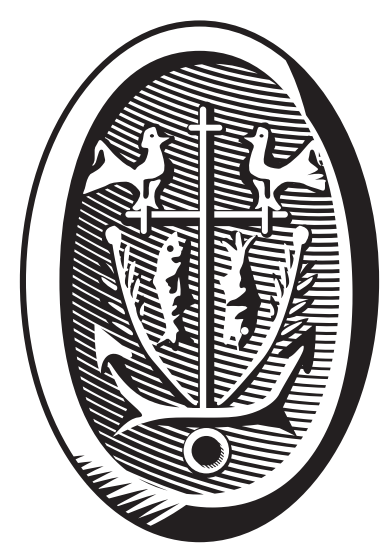

ADRES REDAKCJI

ul. Ludwika Zamenhofa 15, 15-435 Białystok, Polska tel. 85 745-77-80, e-mail: elpis@uwb.edu.pl www.elpis.uwb.edu.pl 